\title{
DEVELOPMENT OF SLOPE AND RELATED SUBSOIL KARST: A CASE STUDY FROM BELA KRAJINA, SE SLOVENIA
}

\section{RAZVOJ POBOČJA IN PRIPADAJOČEGA PODTALNEGA KRASA: PRIMER IZ BELE KRAJINE V JUGOVZHODNI SLOVENIJI}

\author{
Ivan GAMS ${ }^{1}$, Bojan OTONIČAR ${ }^{2} \&$ Tadej SLABE ${ }^{2}$
}

\begin{abstract}
UDC 911.2.551.4(497.434)
Ivan Gams, Bojan Otoničar \& Tadej Slabe: Development of slope and related subsoil karst: A case study from Bela Krajina, SE Slovenia
\end{abstract}

The relief of Bela Krajina and Semiška Reber in southeastern Slovenia is mainly a consequence of post Late Miocene tectonic movements and karstic, mostly subsoil, erosion. In the lower half of the slope at Vrtača in the northwestern part of Bela Krajina, $1.3 \mathrm{~km}$ northeast of the center of Semič and 15 to 25 meters above the surroundings, a 250-meter long and about 150 -meter wide lateral ridge rises at an inclination of $8^{\circ}$. The formation of the medium-sized relief between the elevated lateral ridge and the lower elongated side depressions is most probably to a large extent the consequence of differences in the rock fissuring and the varying intensity of hundreds of thousands of years lasting corrosion related to it. Traces of subsoil formation are the prevailing feature found on hundreds of rock ribs (i.e., subsoil rock formations that are not cone-shaped like teeth but rather elongated with their longer axes largely parallel to the dip of the surface) dissecting the surface area of one of the vineyard plots on the rocky lateral ridge. This indicates they were relatively recently exposed, as a consequence of human activity when soil was removed from an abandoned plot.

Keywords: subsoil rock ribs, lithology, subsoil rock forms and relief, corrosion, denudation, land use, Bela Krajina.
Izvleček

UDK 911.2.551.4(497.434)

Ivan Gams, Bojan Otoničar \& Tadej Slabe: Razvoj pobočja in pripadajočega podtalnega krasa: primer iz Bele Krajine $v$ jugovzhodni Sloveniji

Relief Semiške rebri v Beli Krajini je nastal v glavnem kot posledica tektonskih premikov v obdobju po zgornjem miocenu in kraške, večinoma podtalne, erozije. V spodnji polovici Semiške rebri pri Vrtači v severozahodnem delu Bele Krajine, 1,3 km severovzhodno od središča Semiča, poteka pravokotno na pobočje rebri 15 do 20 metrov visok, 250 metrov dolg in okoli 150 metrov širok greben s padcem površja okoli $8^{\circ}$. Nastanek reliefa med dvignjenim grebenom in stranskima vzdolžnima depresijama je verjetno v veliki meri posledica razlik v razpokanosti kamnine in s tem povezane intenzivnosti dolgotrajne korozije. Več sto skalnih reber se je v glavnem oblikovalo pod tlemi. Pri tem pa so nastale podtalne skalne oblike, ki niso konično oblikovane kot zobje ampak razpotegnjene v smeri vpada pobočja. Ker na površini skalnih reber večinoma ni opaziti dežnih žlebičev menimo, da so bila tla iz opuščenih zemljišč relativno nedavno umetno odstranjena.

Ključne besede: podtalna skalna rebra, litologija, podtalne skalne oblike in relief, korozija, denudacija, raba tal, Bela krajina.

\footnotetext{
${ }^{1}$ Pohorskega bataljona 185, 1000 Ljubljana, Slovenia, e-mail: ivan.gams@guest.arnes.si

${ }^{2}$ Karst Research Institute ZRC SAZU, Titov trg 2, 6230 Postojna, Slovenia, e-mails: otonicar@zrc-sazu.si, slabe@zrc-sazu.si

Received/Prejeto: 4.5.2010
} 


\section{INTRODUCTION}

In the last decade, the accelerated construction of traffic routes and other infrastructure in southeastern Slovenia has revealed numerous karst features of the covered karst of Dolenjska. During excavation work, the covering sediment and soil cover were removed several dozen meters deep, and the bedrock surface was frequently exposed to reveal numerous karst subsoil rock forms as well as underground caves and shafts. In places it was possible to study individual rock teeth several meters in height (up to ten meters) or entire areas of similar rock teeth and ribs that occupied several hundreds or thousands of square meters. While no major construction projects were in progress during this period in the Bela Krajina region, smaller excavations and the remains of older excavation work revealed geomorphological characteristics similar to those in other areas of low covered karst of the Dolenjska region. Because most of the karst here is covered by thick accumulations of sediment and red calcitic cambisol, and distinctive rock teeth and ribs are usually exposed only in limited areas of human encroachment. The existence of larger areas of rock ribs in covered karst landscapes is relatively unusual.

The goal of this study is to determine why only individual plots of land on the $4.5 \mathrm{~km}$ long and 0.4 to 0.8 $\mathrm{km}$ wide relatively straight limestone slope near Semič known locally as "Semiška Reber" display rock ribs that show their subsoil origins generally unchanged by precipitation. In order to explain the reasons for this, we first defined the characteristics of the rock ribs and evaluated the conditions of their origin on the basis of geological and geomorphological criteria.

\section{GEOGRAPHY AND GROSS GEOMORPHOLOGY}

The area studied is located near Semič in the northwestern part of Bela Krajina in southeastern Slovenia (Fig. 1). To the south and east Bela Krajina is bordered by the Kolpa River, to the north by the slopes of the Gorjanci mountain range, and to the west by the Poljanska Gora and Kočevski Rog mountain ranges.

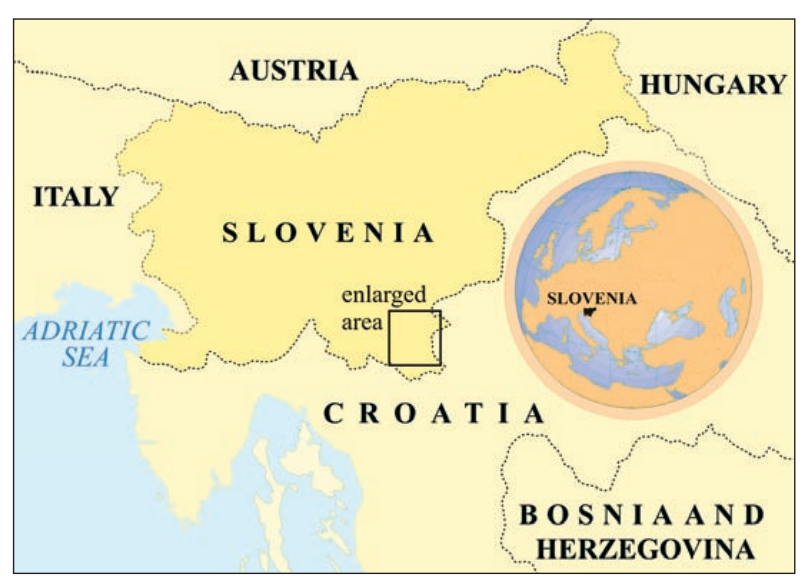

Fig. 1: Geographical location of the area studied (see rectangle).

From the Bela Krajina plain (190-220 m), the westernmost part of the low karst in the hinterland of Karlovac (Croatia), the surface rises to Slovenia's high Dinaric karst in the northwest of Bela Krajina between the Kočevski Rog and Gorjanci mountain ranges in the form of a prominent tectonically induced slope (Fig. 2).

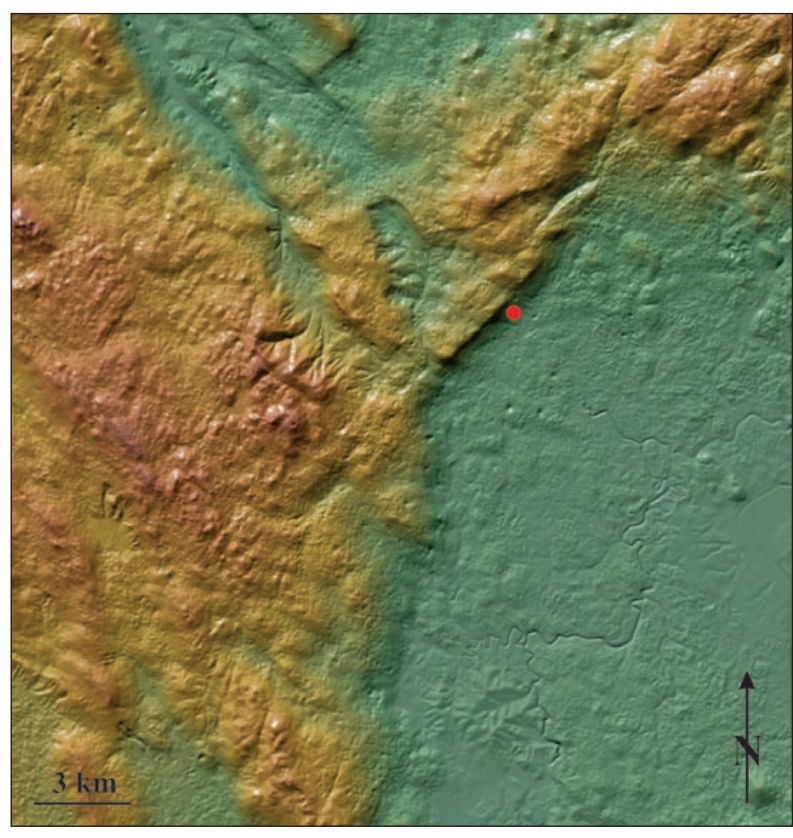

Fig. 2: A digital elevation model of area studied (enlarged area of rectangle in Fig. 1) (Geopedia.si, @Surveying and Mapping Authority of the Republic of Slovenia).

Northeast of Semič the peaks above the slope are between 576 and 626 meters above sea level, the upper edge of the vineyard belt is around 400 meters, and the transition to the Črnomelj plain at the lower edge of the slope lies at an altitude of around 220 meters. The slope here faces 


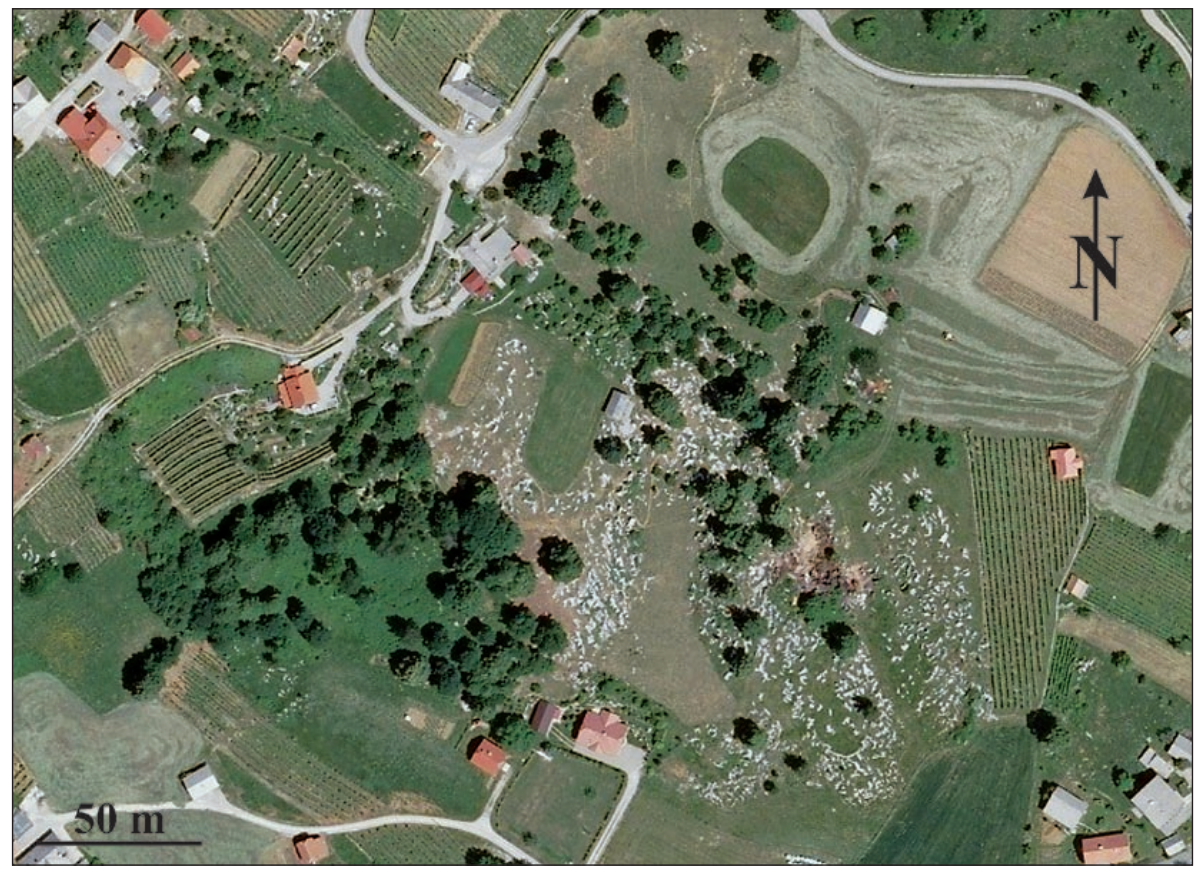

Fig. 3: Microlocation of the studied area with the lateral ridge on which rock ribs are visible (Geopedia.si, (Surveying and Mapping Authority of the Republic of Slovenia).

distinct doline containing a cultivated field (Fig. 3). On the opposite southwestern side of the lateral ridge there is another grassy elongated depression of approximately the same depth. The smaller upper part of the lateral ridge is forested. Cultivated fields dominate to the east of the northeastern depression. There is an inclined flatter area at the top of the lateral southeast, which makes this area exposed to the sun and more suitable for winegrowing than the area to the south of Semič where the slope below the wooded Kočevski Rog mountain range lies in a north-south direction. The average inclination of the entire slope in the area of Semic and above the nearby village of Vrtača is $25^{\circ}$, but its angle decreases downwards. The winegrowing surface is most rocky in its topmost steepest belt where erosion on abandoned vineyards has exposed protruding rocks, usually with truncated tops, and where farmers now bring their cows, sheep, and goats to graze between the bushes and young trees. Below the altitude of 250 meters, cultivated fields and meadows appear among the vineyards.

In the lower half of the slope at Vrtača, $1.3 \mathrm{~km}$ northeast of the center of Semič and 15 to 25 meters above the surroundings, a 250-meter long and about 150-meter wide lateral ridge rises at an inclination of $8^{\circ}$ (Fig. 3). It has an altitude between 245 and 285 meters and runs in a northwest-southeast direction. On the northeastern side of the lateral ridge there is a grassy elongated depression 15 to 20 meters deep whose upper part deepens into a ridge with a meadow in its lower part. Because the surface of the upper part is covered with young trees while the rest is not, the attention is drawn to the bright rock ribs of the lower part. Although there are several areas with rock ribs in the vicinity of the study area, they are smaller and have fewer distinctive rock ribs.

The entire lateral ridge displays hundreds of rock ribs. Their smooth surfaces prove their subsoil origin (Gams 1971; Slabe 2003) and indicate that the ribs have been uncovered from the cover of deposits and/or soil relatively recently. It is surprising that the grassy plots show no sign of surface runoff in the form of channels. They are not found even on the relatively steep sides of the grass-covered lateral ridge. Percolation trough the soil is prevailing.

The average annual amount of precipitation (measured between 1961 and 1990) at the nearby Semič meteorological station (249 m a.s.l.) is $1,264 \mathrm{~mm}$ (Zupančič 1995), 650-700 mm of which evaporates (Kolbezen \& Pristov 1998). The average duration of snow cover at the Semič station is 46 days.

\section{GEOLOGICAL SETTING}

From the geotectonic aspect the studied area belongs to the northeastern part of the Outer Dinaric Mountains, and more narrowly, to the eastern part of the extensive Hrušica nappe (Placer 1999a) or to the Idrija-Central Hungarian transsection zone with its characteristic "crisscross" structure (Placer 1999b). This is also reflected in the wider surroundings of the studied area because it is crisscrossed by numerous faults, generally in the predominant Dinaric (northwest-southeast) and cross-Dinaric (northeast-southeast) directions. The studied elon- 
gated lateral ridge runs in the Dinaric direction. Thus the current geological and geomorphological appearance of the landscape is partly the consequence of pre-Middle or pre-Late Oligocene compression tectonics, and in greater measure to events in the Pliocene (Late Miocene?) and Quaternary that can be related to or are the consequences of the formation of the Idrija-Central Hungarian transsection zone (Placer 1999b).

From the lithostratigraphical viewpoint, the slope above Semič is composed of various Early Cretaceous limestones (Bukovac et al. 1983). Thick layers of grey Aptian limestone dominate in the narrower studied area. From the paleogeographical viewpoint, in the Cretaceous period the area belonged to the northeastern part of the Mesozoic Adriatic carbonate platform (sensu Vlahović et al. 2005), which from the geotectonic viewpoint belonged to the northern part of the Adriatic-Apulian microplate s.s. (sensu Stampfli et al. 1998).

\section{METHODS}

On the ribs, the lithological and basic facies characteristics of the rock were investigated using a field lens. The dip of the strata and the strike of tectonic structural elements were measured with a geological compass and an inclinometer. According to the various lithofacies characteristics, more than ten rock samples were collected from exposed rock ribs for further analyses. All samples were cut to rock slabs, polished, and examined under a binocular laboratory microscope at Karst Research Institute ZRC SAZU. Five thin sections were prepared from selected samples and analyzed using a standard transmitted light microscope supplemented by cathodoluminiscence.

A soil sample for laboratory granulometric analysis was taken from soil excavated from a depth of one to two meters at the contact of the meadow and upper part of the studied lateral ridge covered in young forest. The granulometric analysis was done at the Department of Geography of the Faculty of Arts of the University of Ljubljana.

Rock ribs were measured in the lower meadowy part of the lateral ridge on a horizontal profile crossing the lateral ridge lengthwise from one edge of the upper flat area to the other over a total length of 66 meters. A profile with an average frequency of rock ribs was selected for study. We examined the rock relief on the ribs and various subsoil rock forms.

Carbonate levels in the Krupa spring were determined using the standard titrimetric method (Standard Methods for the Examination of Water and Wastewater 1992).

\section{RESULTS}

\section{Tectonic structures and lithology of the bedrock}

To explain the origin of the rocky patches in this otherwise more or less covered karst landscape, structural, lithological, and standard lithofacies analyses were done on the limestone of exposed rock ribs and surrounding, mainly soil-covered karst areas.

\section{Tectonic structures}

Variously oriented calcite veins and bedding parallel stilolites occur among the structural elements. The limestone of the lateral ridge is dissected by several distinct subvertical fissures and fissure zones striking in two main directions, from NW to $\mathrm{SE}$ (from $305^{\circ}-125^{\circ}$ to $335^{\circ}-155^{\circ}$ ) (Fig. 4 ) and from NE to SW (from $45^{\circ}-225^{\circ}$ to $70^{\circ}-250^{\circ}$ ).

\section{Lithology and lithofacies (fieldwork)}

The bedrock of the exposed rock ribs and the adjacent covered areas is composed of middle to dark grey and even mottled limestone arranged mainly in thick beds with a relatively uniform dip toward the southwest (average $\sim 215^{\circ} / 25^{\circ}$ ) (Fig. 5). Northeast from the rocky lateral ridge, in the area of the large doline, and stratigraphically below the limestone that composes the rock ribs, the limestone is rather more distinctly stratified, denser (micritic), and darker.

On the outcrops (rock ribs), fragments of rudist and gastropod shells and peloids are abundant in some beds while oncoids are less common. Locally, different lithofacies are arranged in shallowing upward parasequences [rudist floatstone $(\mathrm{F}) \rightarrow$ oncoidal/peloidal wackstone $(\mathrm{W}) \rightarrow$ fenestral mudstone $(\mathrm{M})$ or biotur- 


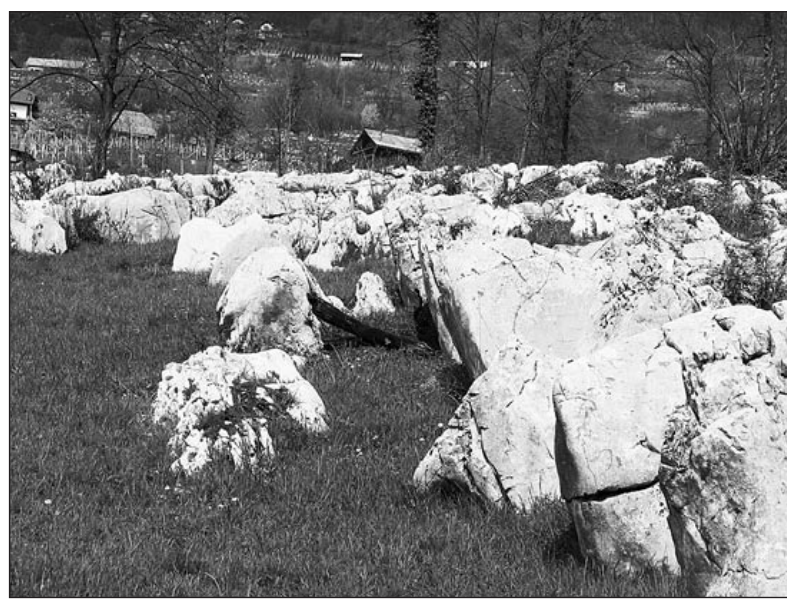

Fig. 4: Distinctly visible fissure zone in the form of a shallow, approximately one meter high trench with soil-covered bottom (Photo: B. Otoničar).

bated oncoidal/peloidal wackstone/mudstone $(\mathrm{W} / \mathrm{M}) \rightarrow$ fenestral mudstone $(\mathrm{M})$ ].

\section{Lithofacies}

According to the standard descriptive criteria for sedimentary textures, the analyzed thin sections were classified into three different lithofacies:

- Three thin sections were prepared from samples collected in the abandoned vineyard with eroded soil and truncated rocks higher on the slope of the lateral ridge immediately above the central part of the study area. The samples belong to relatively unhomogenous miliolidalpeloidal packstone (P) (Figs. $6 \& 7$ ) that contain mainly poorly sorted foraminiferas (miliolidae, textularidae, etc.) (Fig. 6), "Lithocodium/Bacinella" microbial netlike matter (Fig. 7), and peloids (Fig. 6). The matrix is composed of partly washed clotted micrite (Fig. 6). The primary (intergranular and intrafossil) and secondary

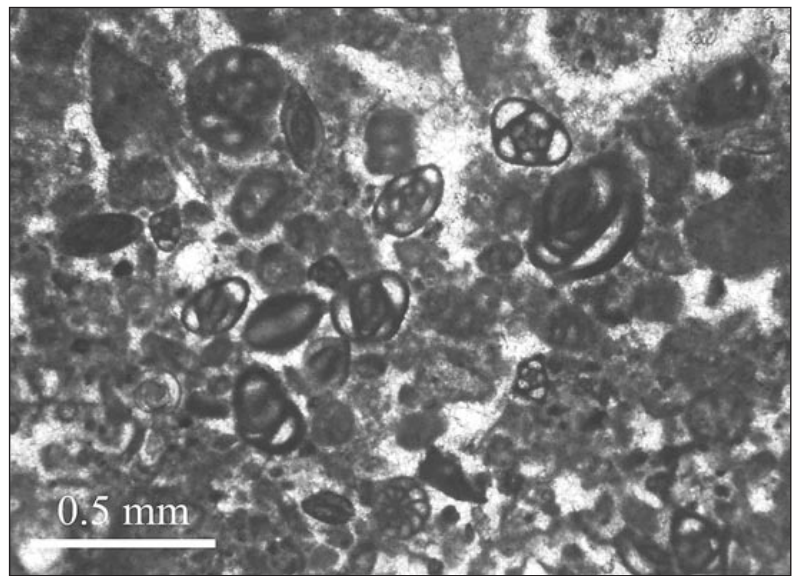

Fig. 6: Lithofacies of miliolidal-peloidal packstone (P) (Photo: $B$. Otoničar).

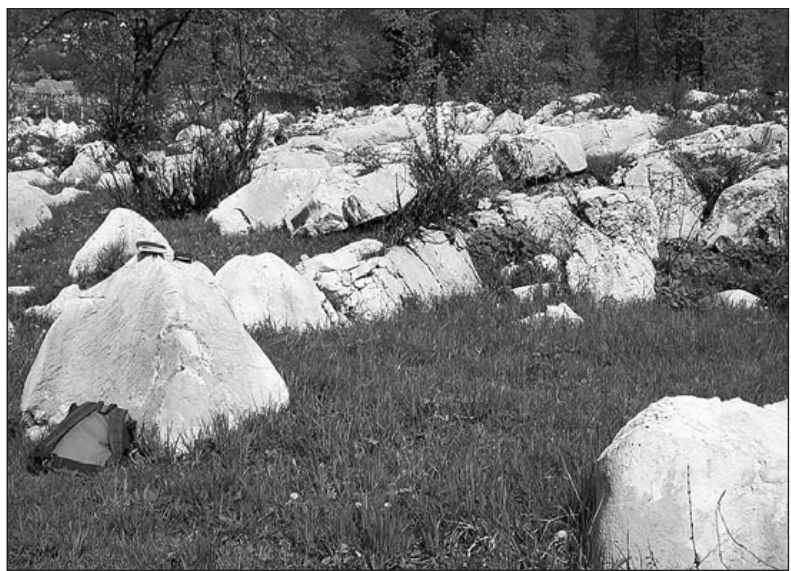

Fig. 5: Distinctive notch formed along bedding plane partings (Photo: B. Otoničar).

pores (bioturbational, mouldic, and dissolutional) are filled with equant mosaic calcite spar (Figs. $6 \& 7$ ). The samples are dissected by fissures and veins up to $2 \mathrm{~mm}$ wide (on average less than $1 \mathrm{~mm}$ ) filled with calcite cement. Individual fissures up to $3 \mathrm{~mm}$ wide are coated with nonluminescent equant calcite spar and filled with yellowish-brown silty calcareous sediment.

- The thin section prepared from the rock sample taken from the northern edge of the elongated depression that runs northeast from the rocky lateral ridge belongs to biogenic (silty) wackestone (W) (Fig. 8) with characteristic orbitolinid foraminiferas, most probably belonging to the species Palorbitolina lenticularis (Fig. 8). Along with orbitolinid and some other smaller foraminiferas, the wackestone lithofacies includes numerous biogenic debris derived mainly from mollusks and less commonly from echinoderms. Among non-skeletal grains, peloids occur. Because of their dense packing, they are not very distinct and as such pass over to the

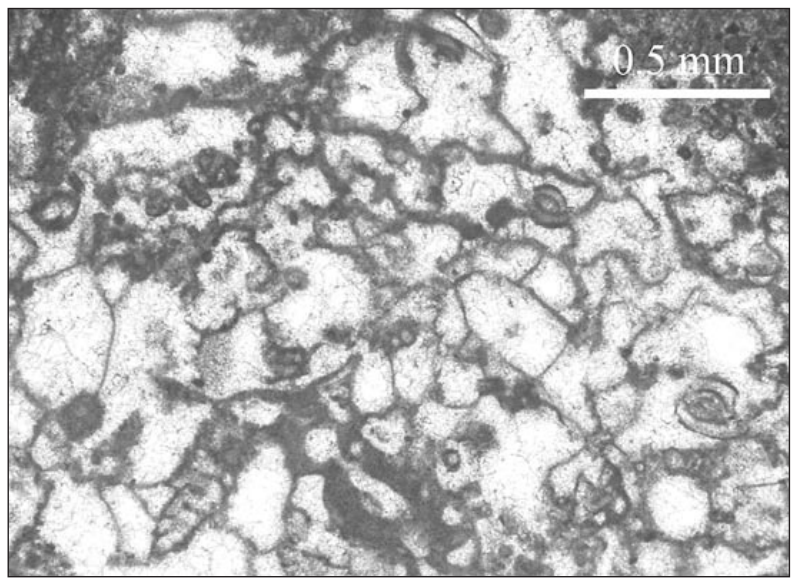

Fig. 7: "Lithocodium/Bacinella" microbial netlike matter (Photo: B. Otoničar). 


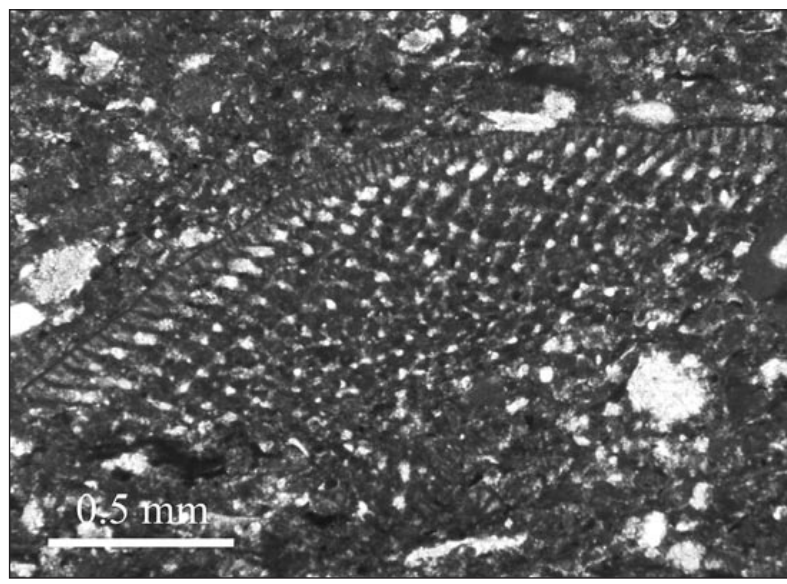

Fig. 8: Litofacies of biogenic (silty) wackestone (W) with Palorbitolina lenticularis (Photo: B. Otoničar).

clotted micrite that forms the matrix of the wackestone. The sample is dissected by individual calcite veins less than $0.05 \mathrm{~mm}$ wide.

- The sample taken from the lower, more grassy part of the study area is characterized by peloid-algal wackestone/mudstone (W/M) (Fig. 9) that contains individual larger rounded bioclasts, micrite intraclasts, and peloids. To various amounts, the micritized bioclasts include cyanobacterial matter ("Cayeuxia" spp.), ostracods, and foraminiferas, especially tiny miliolids. The matrix is composed of dense micrite with patches of less dense sediment where non-skeletal grains are more visible. These patches, which make the sample appear unhomogenous, are most probably bioturbational in origin. The sample is dissected by several generations of veins up to $1 \mathrm{~mm}$ wide. They are filled with a slightly brownish but clear mosaic, commonly equant, calcite spar.

\section{Age of carbonate succession}

The age of the examined limestone was determined by the presence of foraminifera Palorbitolina lenticularis (Fig. 8), which for the Adriatic carbonate platform is typical of the Early Aptian (Šribar 1979; Husinec et al. 2000; Husinec 2001). The association of $P$. lenticularis and "Bacinella irregularis" (Fig. 7) is also very common in Lower Aptian deposits of the northwestern Adriatic carbonate platform (Šribar 1979; Husinec et al. 2000). The darker stained micritic lithofacies of the examined carbonate succession with common microbial carbonates could be related to the first Cretaceous oceanic anoxic event (OAE1a), which also corresponds to the Early Aptian (Immenhauser et al. 2009). Indirectly, the Aptian age of the limestone could be suggested by the dissolutionally enlarged fissures filled with meteoric ce-

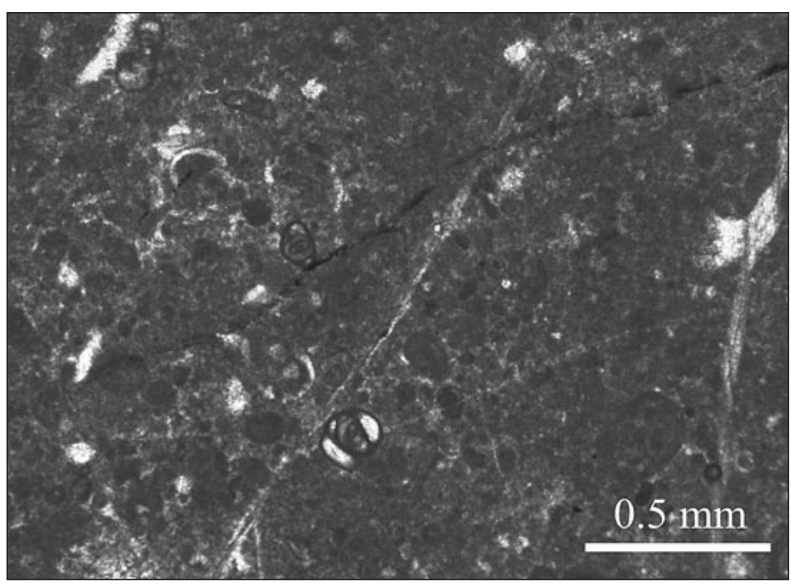

Fig. 9: Litofacies of peloidal wackestone (W) (Photo: B. Otoničar).

ment and silt that can also be related to Aptian/Albian subaerial exposure event recorded in various parts of the Adriatic carbonate platform (Velić et al. 1989; Jurkovšek et al. 1996).

\section{Soil}

The soil exhibits the characteristics of terra rossa with a dominant fraction of clay. According to the percentage of weight relative to grain size, clay dominates (61.7\%) followed by silt (34.9\%) and small fractions of sand (1.79\% fine sand and $1.61 \%$ coarse sand).

On the nearby Straška Gora ridge, which has an $18^{\circ}$ inclination, the proportion of different fractions in the percentage by weight of soil particles deposited at the lower end of the vineyard is as follows (Ravbar 1970):

\begin{tabular}{l|l|l}
\hline Fraction & After moderate rain, \% & After heavy rain, \% \\
\hline below $0.1 \mathrm{~mm}$ & 1 & 3 \\
\hline $0.2-0.1 \mathrm{~mm}$ & 4 & 11 \\
\hline $0.2-0.5 \mathrm{~mm}$ & 12 & 24 \\
\hline $0.5-2 \mathrm{~mm}$ & 72 & 45 \\
\hline above $2 \mathrm{~mm}$ & 11 & 17 \\
\hline
\end{tabular}

\section{Amount of dissolved carbonates}

According to our analysis, one liter of water in the Krupa spring, a karst tributary of the nearby Kolpa River, contains around $219 \mathrm{mg}$ of carbonates.

\section{Rock relief of the rock ribs}

We counted sixteen rock ribs in the selected 66 meter long profile. The average distance between two adjacent rock ribs is 1.74 meters (smallest distance 1.2 $\mathrm{m}$; greatest distance $2.9 \mathrm{~m}$ ). The average height of the 


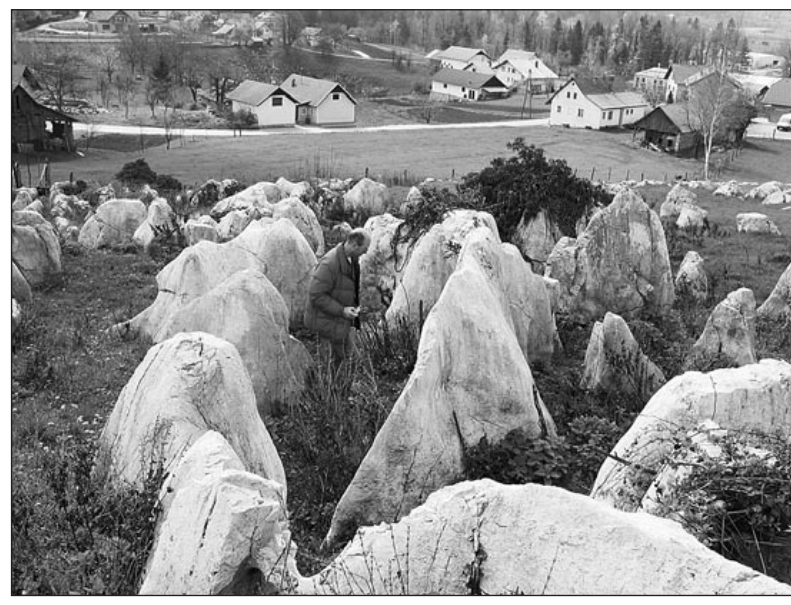

Fig. 10: Rock ribs with large subsoil channels and corridors between them (Photo: T. Slabe).

ribs is 175 centimeters (shortest $52 \mathrm{~cm}$; tallest $200 \mathrm{~cm}$ ). The cross sections of the rock ribs on average measure $342 \mathrm{~cm}$ perpendicular to the profile and $260 \mathrm{~cm}$ parallel with the profile. The size of the rock ribs increases downhill. The rock ribs are therefore not cone-shaped like teeth but rather elongated; their longer axes are largely parallel to the dip of the lateral ridge. With the decreasing inclination of the lower part of the slope, the rock ribs become shorter and less frequent. The slope without rock ribs gradually levels out, first in a meadow and then a cultivated field before it reaches the asphalt road leading from Semič to Jugor (Figs. 3, $4,5,10 \& 11)$.

The subsoil rock forms (see Gams 1971; Slabe \& Liu 2009; Knez \& Slabe 2010) that cover the surface of the rock ribs can be divided into two types. The first are traces of underground water creeping in the direction of the dip of the lateral ridge, and the second of the vertical percolation of water from the surface. Rainwater and vegetation have reshaped the rock forms to a smaller degree only on the lower part of the lateral ridge where the tops of the rock ribs have been exposed for a longer period.

Subsoil channels and corridors meander between the rock ribs (Figs. $10 \& 12$ ), their prevailing direction following the dip of the lateral ridge. The cross sections of the upper parts of the channels are up to one meter wide or more and narrow downwards. Often only their bottoms remain covered by soil. As a rule, the corrosion of rock is faster under the soil so the walls of channels can be undercut to form an overhang. Exposed traces of subsoil channels that originally formed below the ground are found over the entire height of rock ribs (Fig. 12), even on the tops, which are in places dissected into a number of points. They are proof of the rapid exposure of the rock.

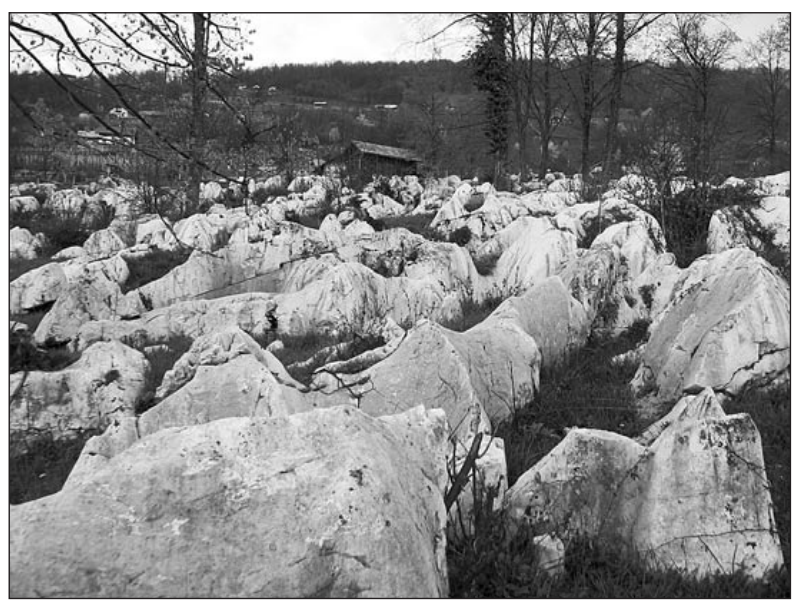

Fig. 11: Field of rock ribs (Photo: T. Slabe).

Subsoil tubes (Fig. 13) form along weak points in the rock, usually at bedding planes. The prevalent orientation of the tubes follows the inclination of the surface. They are around one decimeter in diameter, and the shape of the cross section indicates the manner of their formation, which is linked to the filling of the tubes with fine-grained alluvium or soil transported by water from the surface. They have rounded cross sections that along the bedding planes widen into an elliptical shape,

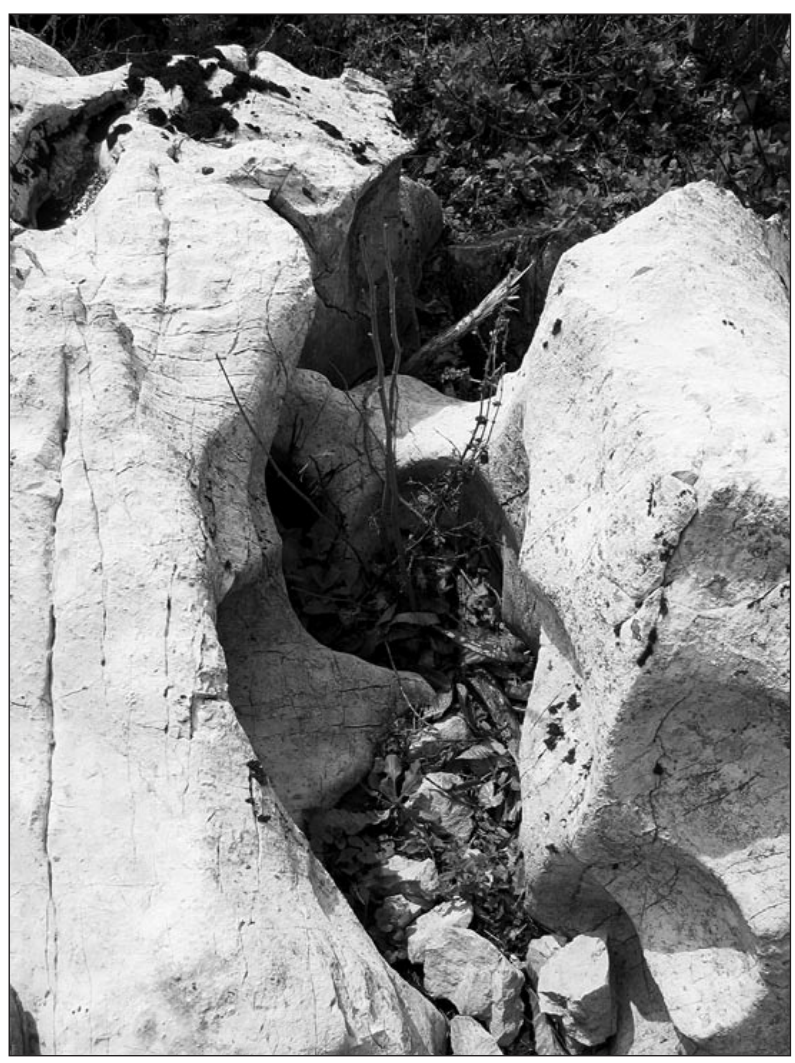

Fig. 12: Subsoil channel (left), width of view is $1 \mathrm{~m}$ (Photo: T. Slabe). 


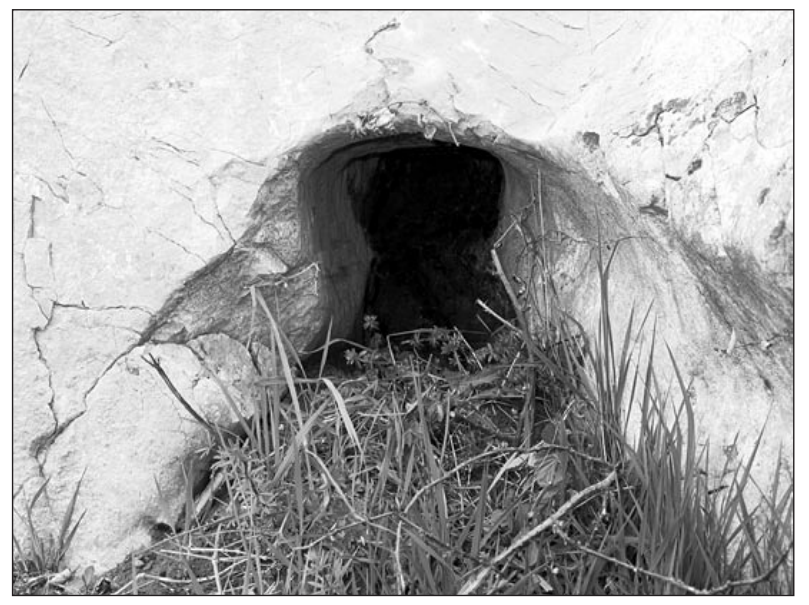

Fig. 13: Subsoil tube, width of view is $0.75 \mathrm{~m}$ (Photo: T. Slabe).

in most cases reflecting paragenesis (i.e., rising above the alluvium). Water continuously filled them with alluvium that settled in the lower section of the tube, and the water carved its way upward. The bottoms of tubes, which lie on the bedding planes, are more or less flat, while their upper parts arch above them in a semicircular manner acquiring the shape of the Greek letter omega. Abovesediment channels have widened the upper parts of the cross sections of some subsoil tubes, and there are notches at the mouths of the tubes. The lowering of the layer of soil that covered or surrounded the rock ribs caused the tubes which remained at the new level of soil to deepen with below-sediment channels.

Funnel-like notches (Fig. 14) and vertical subsoil channels formed by the percolation of water from the surface are the most distinct of all subsoil rock forms. Funnel shaped vertical notches reaching one or two meters in diameter in their upper sections are the consequence of water percolating evenly through the soil and creeping downward along the contact with the rock. Immediately below the soil, the water corrodes the rock evenly across the entire surface, and farther below the

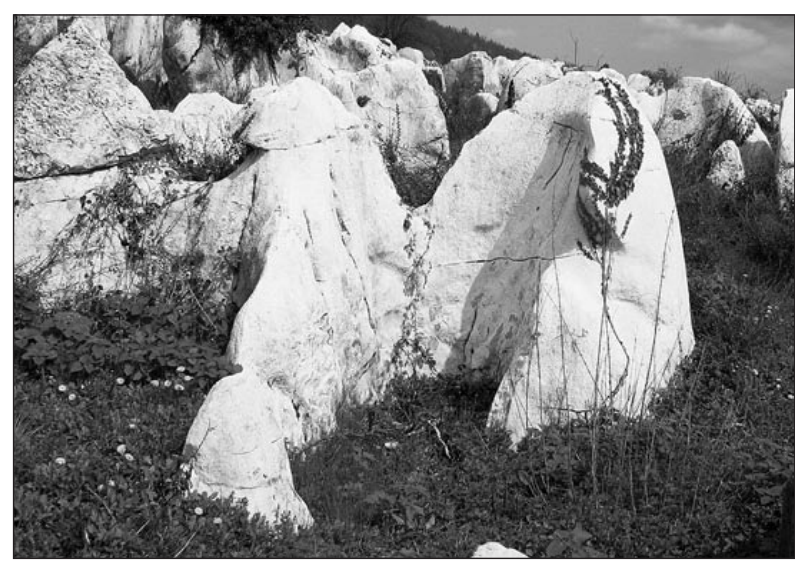

Fig. 14: Funnel-like notch, width of view is $3 \mathrm{~m}$ (Photo: T. Slabe). surface, it often consolidates into a single stream. The notches narrow distinctly into channels. Vertical channels formed on the walls of the rock ribs along vertical fissures.

There are notches on the walls of rock ribs and on larger subsoil channels that formed when meandering channels corroded deep into the rock or when water creeping down an overhanging wall corroded a half-bell notch (Slabe 2003). A deeper channel forms on the lower section of half-bell notches.

Rock forms carved by precipitation, primarily rain, include flutes (Fig. 15) and solution pans (Fig. 16). Flutes can only be found on the tops of individual rock ribs since few of them have been exposed for a longer pe-

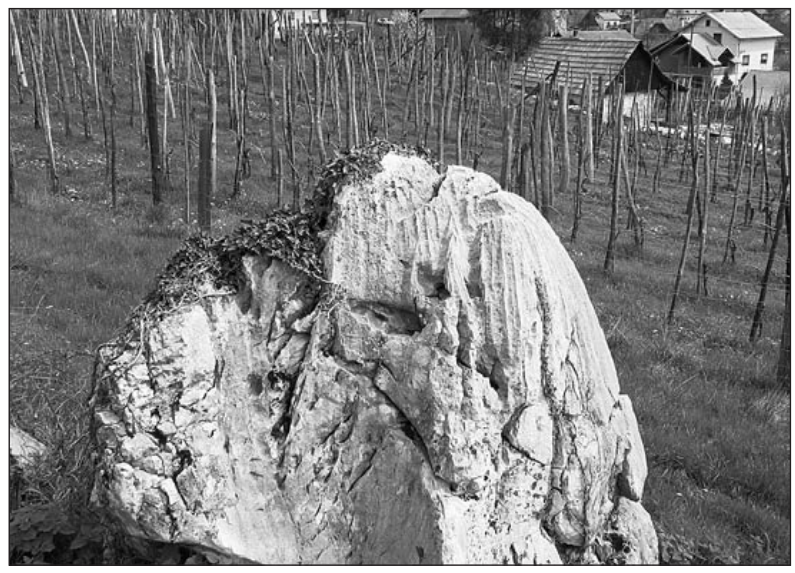

Fig. 15: Rain flutes (Photo: T. Slabe).

riod and the shape of the rock ribs is completely dominated by their subsoil formation. The relatively rare solution pans developed from denuded subsoil cups (Gams 1971). Solution pans display a variety of forms, depending on their position on the rock where overflowing is possible during abundant rain, the fissuring of the rock, and the stage of their development under the ground or on the surface. Their walls are flat and gently sloping or overhanging.

Several types of rock surface can be distinguished with the naked eye. Smooth surfaces, the consequence of subsoil rock formation, dominate. In places, denuded rocks were reshaped below a cover of vegetation such as ivy. Under the vegetation cover, the rock is distinctly dissected along tiny fissures, and in places it has broken into small pieces (Fig. 17). On the shady side the rocks are overgrown with moss, which also weathers the rock in a unique manner. Under moss, small recesses a few millimeters in diameter occur. The corrosion of rock under a moss cover seems accelerated, which is especially evident from the more distinct dissection along fissures. 


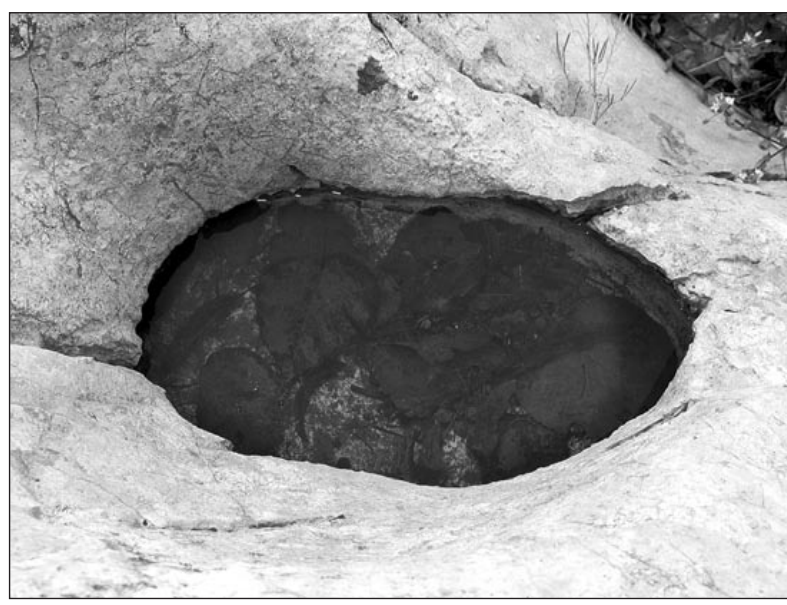

Fig. 16: Solution pan, width of view is $0.4 \mathrm{~m}$ (Photo: T. Slabe).

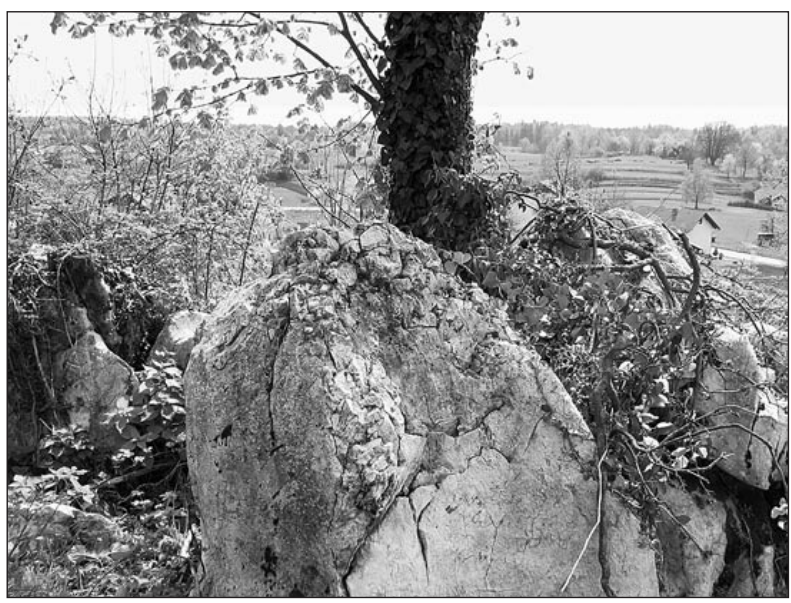

Fig. 17: Under vegetation disintegrated rock (Photo: T. Slabe).

\section{DISCUSSION}

As mentioned above, the several-hundred-meter high slope at the southern and western edge of the Črnomelj plain is to a large degree the consequence of tectonic events in the Late Miocene, Pliocene, and Quaternary when Pontian (Late Miocene) lake marls and clays with coal were deposited in the sinking depression at the foot of the slope. Bukovac et al. (1983) believe Pontian sediments belong to the Pliocene, but according to the latest classifications the Pontian stage is the last stage of the Miocene. The so-called "crisscross" structural-tectonic composition of Bela Krajina can also be placed in this period (sensu Placer 1999b).

The limestone bedrock was later reshaped mainly by chemical and exogenous subsoil processes. The shape of rock ribs and their rock relief reveal the manner of their formation. They developed as subsoil karren that were exposed rapidly. They still bear the unmistakable stamp of subsoil formation even though they are currently being transformed by precipitation and the vegetation cover. The rock ribs examined at Semič are somewhat similar to those uncovered during the construction of the small industry zone at Trebnje fifty kilometers away (Knez et al. 2003). The difference is that at Semic the ribs have unique shape developed on slope and the rock is composed of fine-grained limestone while at Trebnje rock teeth are developed on relatively flat surface and the rock is composed of dolomitized limestone and coarse-grained dolomite breccia. Subsoil features were uncovered at numerous locations during the construction of the Dolenjska sections of the Karavanke-Obrežje expressway (Knez \& Slabe 2006, 2007).
Although theoretically soil moistness or precipitation water corrode micrite limestone faster than sparitic limestone due to the smaller relative surface of the carbonate grains that compose homogenous micrite limestone, this can not be the reason for the occurrence of rock ribs in our case. In particular, the lithofacies analyses presented indicate that there are no significant differences between the lithology and lithofacies of covered and uncovered parts of the investigated area. We suggest that some specific textural characteristics of the limestone such as the locally numerous macrofossils (i.e., rudist shells) and calcite veins may influence the appearance of the rocky relief on a small scale but not the occurrence and appearance of the subsoil rock ribs.

It is possible that fissuring of the rock plays an important role in the appearance (relief) of the studied area because the more fissured and angular surface of the bedrock has a larger specific surface area and therefore a relatively larger corrosion-active contact with aggressive soil moistness (Gams 2000, 2004). Because the adjacent comparable area remains covered, we have not been able to provide proof for this statement; however, some fissures or fissure zones are distinctly visible in the rocky relief in the form of shallow, approximately one-meter high walls and trenches commonly with soil-covered bottoms (Fig. 4). Locally, distinct notches also appear along eroded bedding planes partings (Fig. 5). It is also possible that the formation of the relief on a slightly larger scale, namely the elevated lateral ridge and the lower elongated side depressions, is to a large extent the consequence of differences in the rock fissuring and the varying intensity of corrosion related to it since the orientation of the lon- 
ger axes of these relief features corresponds to the orientation (NW-SE) of one of the main tectonic structures of the area.

Although granulometric measurements at the nearby Straška gora slope established that the size of grains of soil particles carried down the slope and deposited at the lower end of the vineyard also depends on the form of the precipitation, erosion from steep slopes generally deposits more coarse-grained than fine-grained particles at the bottom of the vineyards. Comparing this data with ours, we can conclude that the terra rossa on our slope was not transported from higher positions because the clay component dominates distinctly; however, we must be cautious with this assertion because the dominant component may be the result of the composition of the original material. It is quite possible that the terra rossa originates from relatively thin pedogenically modified Miocene, Pleistocene, and/or Quaternary sediments deposited on the probably already karstified karst surface formed on Early Cretaceous limestone.

Higher up the Semiška Reber slope above the study lateral ridge, the terra rossa layer was probably shallow at inclinations above $18^{\circ}$ even before agrarian land use. Following an old Bela Krajina practice, the turf is removed from ploughed vineyards. Heavy rains have therefore always caused heavy soil erosion. In the $19^{\text {th }}$ century at sites similar to the Semiška Reber slope, winegrowers on the Ljuben hill ten kilometers away used to carry the eroded loam in baskets from the vineyard areas to the top of the "mountain" (Hrovat 1953) and because of erosion abandoned older vineyards on the steepest slopes. The annual measured erosion-related lowering of the ground on tilled (cultivated fields, vineyards, etc.) inclined slopes in Slovenia totals $2.25 \mathrm{~mm}$ (Komac \& Zorn 2005) or 2.25 meters per thousand years. The age of the Semic vineyards is unknown, but the soil erosion on their steep slopes in particular could be severe. Since like everywhere else in Slovenia, vineyards were presumably introduced to this region by the Romans, the oldest vineyards could theoretically be almost two thousand years old. Over this period of time the estimated rate of soil erosion could have lowered the surface of the steep slopes by four meters.

The intensity of corrosion in the studied area can be assessed by the amount of dissolved carbonates in the Kolpa River, which is fed by tributaries from Bela Krajina and the wider surroundings. The assessed lowering of the surface for the entire Kolpa River basin totals 6070 microns per year or the same number of meters in a million years (Gams 2004). If the difference in the relief between the lateral ridge and the elongated side depressions is exclusively of corrosion origin, we can conclude that the height difference between the lateral ridge and the two grassy covered depressions is the result of more than a million years of uneven corrosion. If corrosion had no effect on the elevated lateral ridge and only acted at the estimated rate in the depressions, it would take at least 300,000 years for the twenty-meter relief difference to form. Even if other processes are not considered (tectonic movements, erosion, etc.), we must still be careful with this assessment since we know neither what the relief looked like before the deposition of sediments nor the age and original thickness of the sediment cover over the carbonate bedrock. We therefore also do not know exactly the intensity of corrosion relative to the thickness of the clayey cover and the fissuring of the rock or when the corrosion under the clayey cover became possible.

The absence of erosion gullies on the gently sloping $\left(8^{\circ}\right)$ meadow surface indicates that the soil in this area is capable of absorbing more water than it receives during normal rains, even though according to the granulometric data the soil is quite clayey.

On the early $19^{\text {th }}$ century Franciscan cadastral map (Archives of the Republic of Slovenia), a vineyard is drawn on the studied lateral ridge. According to local residents, its owner and his entire family emigrated to the United States at the end of $19^{\text {th }}$ century. The accelerated soil erosion at the lower part of the lateral ridge could therefore have lasted from the original planting of the vineyard until the end of the $19^{\text {th }}$ century when the overgrowth later slowed the erosion. If the erosion had occurred due to the washing away of the soil, the process would have taken at least seven hundred years, considering the height of the rock ribs (average of $1.75 \mathrm{~m}$ ) and assuming that when the erosion began the tops of the rock ribs were close to the surface. The surface of the upper part of the lateral ridge is overgrown by trees and bushes and is not completely flat. The rock ribs exhibit the first signs of the fine dissection of smooth surfaces due to the more aggressive raindrops falling from the leaves of the trees. The lower part of the lateral ridge on our study plot shows no such signs of corrosion.

If the rock ribs on the lateral ridge had existed when the vineyard was actively cultivated, the owner would have cut their tops off to match the erosion of the soil. Winegrowers in Dolenjska still follow this practice. Our rock ribs, however, show no sign of such action. The only remaining explanation is that when the owner of the vineyard on the upper part of the lateral ridge left the country, neighbouring farmers removed the soil from his plot to use in their own vineyards. Asked about this possibility, the local farmers denied it, probably because there is a possibility that the descendants of the former owner might someday return. This relatively recent encroachment is the only explanation for the minimal corrosion of the still mostly smooth surfaces of the ribs. 


\section{CONCLUSION}

The Semiška Reber slope was originally part of the Crnomelj plain. Since the Late Miocene, tectonic movements have caused changes in the relief on its western margin. In the Pleistocene, erosion on the less inclined lateral ridge on the Semiška Reber slope $\left(8^{\circ}\right)$ was smaller than in the elongated side depressions, which deepened at a faster rate. Due to its smaller inclination, less surface washing, and better exposure to the sun, the higher part of the lateral ridge offered better conditions for winegrowing. After the owner of the best vineyard in the area emigrated to the United States with his entire family before World War I, neighbouring farmers took advantage of the situation to transfer the soil to their own more or less eroded plots.

Determining the exact Early Albian age of the limestone bedrock of the studied area and establishing that the lithological composition of the limestone in this area does not determine the occurrence and absence of rock ribs are two "byproducts" of our study.

\section{REFERENCES}

Archives of the Republic of Slovenia, Ljubljana.

Bukovac, J., Poljak, M., Šušnjar, M. \& M. Čakalo, 1983: Osnovna geološka karta SFRJ, List Črnomelj. 1:100.000.- Beograd.

Gams, I., 1971: Podtalne kraške oblike.- Geografski vestnik, 43, 27-45.

Gams, I., 2000: Doline morphogenetic processes from global and local vievvpoint.- Acta Carsologica, 29, 2, 123-138.

Gams, I., 2004: Kras v Sloveniji v prostoru in času.Založba ZRC SAZU, pp. 515, Ljubljana.

Hrovat, A., 1953: Kraška ilovica, njene značilnosti in vpliv na zgradbe.- Državna založba Slovenije, pp. 190, Ljubljana.

Husinec, A., 2001: Palorbitolina lenticularis from the northern adriatic region: paleogeographical and evolutionary implications.- The Journal of Foraminiferal Research, 31, 4, 287-293.

Husinec, A., Velić, I., Fuček, L., Vlahović, I., Matičec, D., Ostrić N. \& T. Korbar, 2000: Mid Cretaceous orbitolinid (Foraminiferida) record from the islands of Cres and Lošinj (Croatia) and its regional stratigraphic correlation.- Cretaceous Research, 21, 1, 155-171.

Immenhauser, A., Huck, S., Rameil, N., Heimhofer, U., Korbar, T., Wieczorek, T.D. \& C. Kunkel, 2009: Tethys-wide occurrence of Lower Aptian Lithocodium-Bacinella facies: Shoalwater expression of basinal OAE1a black shales.- Geochimica et cosmochimica acta, 73, 13, A568-A568.

Jurkovšek, B., Toman, M., Ogorelec, B., Šribar, L., Drobne, K., Poljak, M. \& L. Šribar, 1996: Formacijska geološka karta 1:50.000 južnega dela TržaškoKomenske planote.- Inštitut za geologijo, geotehniko in geofiziko, pp. 143, Ljubljana.
Knez, M., Otoničar, B. \& T. Slabe, 2003: Subcutaneous stone forest (Trebnje, Central Slovenia).- Acta Carsologica, 32, 1, 29-38.

Knez, M. \& T. Slabe, 2006: Dolenjska subsoil stone forests and other karst phenomena discovered during the construction of the Hrastje - Lešnica motorway section $($ Slovenia) $=$ Dolenjski podtalni kamniti gozdovi in drugi kraški pojavi, odkriti pri gradnji avtocestnega odseka Hrastje - Lešnica.- Acta Carsologica, 35, 2, 103-109.

Knez, M. \& T. Slabe, 2007: Kraški pojavi, razkriti med gradnjo slovenskih avtocest.- Založba ZRC, Carsologica, pp. 250, Postojna-Ljubljana.

Knez, M., Liu, H. \& T., Slabe, 2010: High mountain karren in northwestern Yunnan, China.- Acta carsologica 39, 1, 103-114.

Kolbezen, M. \& J. Pristov, 1998: Površinski vodotoki in vodna bilanca Slovenije.- Hidrometeorološki zavod Republike Slovenije, pp. 98, Ljubljana.

Komac, B. \& M. Zorn, 2005: Soil erosion on agricultural land in Slovenia - measurements of soil erosion in the Besnica Valley.- Geografski zbornik, 45, 1, 32-53.

Placer, L., 1999a: Contribution to the macrotectonic subdivision of the border region between Southern Alps and External Dinarides.- Geologija, 41, 223255.

Placer, L., 1999b: Structural meaning of the Sava folds.Geologija, 41, 191-221.

Ravbar, M., 1970: Erozija prsti na nagnjenem kraškem področju v okolici Straže.- Seminar paper. Filozofska fakulteta Univerze v Ljubljani, pp. 25, Ljubljana.

Slabe, T., 2003: Subcutaneous rock forms.- Acta Carsologica 28, 2, 255-271. 
Slabe, T. \& H. Liu, 2009: Significant subsoil rock forms.In: Ginés, A. et al. (eds.) Karst rock features: karren sculpturing. Carsologica, 9, ZRC Publishing, pp. 123-137, Ljubljana.

Stampfli, G.M., Mosar, J., Marquer, D., Marchant, R., Baudin, T. \& G. Borel, 1998: Subduction and obduction processes in the Swiss Alps.- Tectonophysics, 296, 1-2, 159-204.

Standard Methods for the Examination of water and Waste Water, 1992, $18^{\text {th }}$ Edition, Washington.

Šribar, L., 1979: Biostratigrafija spodnjekrednih plasti na Logaški planoti $=$ Biostratigraphy of Lower Cretaceous beds from the Logatec Plain.- Geologija, 22, 2, 277-308.
Velić, I., Tišljar, J. \& B. Sokač, 1989: The variability of thicknesses of the Barremian, Aptian and Albian carbonates as a consequence of changing depositional environments and emersion in Western Istria (Croatia, Yugoslavia).- Mem. Soc. Geol. Ital. (1987), 40, 209-218.

Vlahović, I., Tišljar, J., Velić, I. \& D. Matičec, 2005: Evolution of the Adriatic carbonate platform: Palaeogeography, main events and depositional dynamics.- $\mathrm{Pa}$ laeogeography Palaeoclimatology Palaeoecology, 220, 3-4, 333-360.

Zupančič, B., 1995: Klimatografija Slovenije. Padavine 1961-1990.- Hidrometeorološki zavod Republike Slovenije, pp. 366, Ljubljana. 